\title{
Does road salt affect groundwater in Denmark?
}

\author{
Søren M. Kristiansen, Flemming D. Christensen and Birgitte Hansen
}

Chloride $(\mathrm{Cl})$ from dissolved salt is a major threat to groundwater quality in many regions of the world. In arid regions near present-day coastlines, where old seawater occurs in deeper sediments and where road salt is frequently used, $\mathrm{Cl}$ can be a significant pollutant (European Environmental Agency 2009). European Union member states have recently reported that next to nitrogen, $\mathrm{Cl}$ is the most commonly found pollutant and is often responsible for groundwater bodies being at risk or having a poor ecological status (European Commission 2010).

Intrusion of salty groundwater and infiltration by seawater near coastlines are well-known phenomena in Danish aquifers (Ødum \& Christensen 1936; Bonnesen et al. 2009). Saltwater in aquifers may also come from human pollution such as landfills, road salt storage facilities, roads and agricultural activities (Panno et al. 2006). Since the 1970s, deicing salt applied to roads has been recognised as a significant source of contamination that may deteriorate aquifers that are used as drinking water resources by increasing their $\mathrm{Cl}$ concentration and by harming stream and lake ecosystems (Jackson \& Jabbogy 2005). Recent studies have suggested that the decade-long usage of road salt is becoming a rising threat to groundwater quality (Bester et al. 2006). Salt contamination from roads is therefore particularly problematic to aquifers already at risk (Lundmark \& Olofsson 2007). The present paper explores the impact of road salt on groundwater quality in Denmark by means of a combination of chemical indicator analysis, temporal and spatial $\mathrm{Cl}$ analysis and numerical groundwater modelling.

The vulnerability of aquifers to road salt depends on the amount of salt applied per kilometre road, the degree of urbanisation and the percentage of salt lost to the subsurface. Based on a literature review, the estimated percentage of road salt lost to the groundwater is $10-20 \%$ of applied de-icing salt in Danish urban areas (Kristiansen et al. 2009). The average amount of road salt used during the winter in Denmark has risen since the late 1990s, but varies with weather conditions (Fig. 1). In comparison, Fig. 1 also shows that the atmospheric $\mathrm{NaCl}$ deposition for the entire Danish surface area is about 280 gigagrams $(\mathrm{Gg})$ per year, which is tentatively estimated based on actual bulk deposition measurements (T. Ellerman, personal communication 2011). Thus, the total amount of applied road salt and the total atmospheric salt deposition in
Denmark are of the same order of magnitude. However, the local surface load of road salt and atmospheric salt deposition vary widely across Denmark.

\section{The Danish road salt project}

This paper addresses the results from a recent assessment performed under the Danish groundwater mapping project in order to evaluate the impact and risk of road salt to the quality of Danish groundwater resources (Kristiansen et al. 2009). The project used groundwater quality data from the national database Jupiter. The data were downloaded in October 2008 and included approximately 140000 analyses from approximately 24000 groundwater sampling points corresponding to about one sample per $2 \mathrm{~km}^{2}$. The oldest data are from 1890, the most recent from 2007. Data on the historical consumption of road salt were drawn from the Danish Road Directorate and involved municipalities.

Three different methods were used: (1) Evaluation of indicators to separate chloride sources in groundwater chemistry, (2) analysis of the distribution and variation of $\mathrm{Cl}$ in time and space, and (3) development of a numerical groundwater risk assessment tool in the hydrological modelling system MIKE SHE.

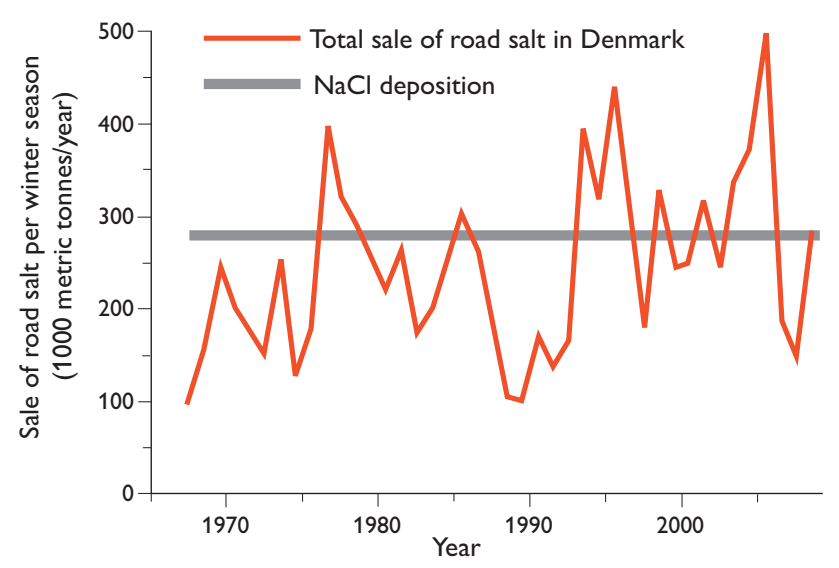

Fig. 1. Sale of road salt for highway use in Denmark from 1965/1966 to 2008/2009 in 1000 metric tonnes $(\mathrm{Gg})$ per winter season based on data from the Danish Road Directorate. Atmospheric $\mathrm{NaCl}$ deposition in $\mathrm{Gg}$ per year is a tentative estimate for the entire Danish surface area based on bulk deposition measurements by T. Ellerman, University of Aarhus, 2011. 


\section{Chloride source indicators}

Geochemical tools with mass ratios of especially the halides have proved useful for identifying different groundwater $\mathrm{Cl}$ sources (Davies et al. 1998). Groundwater salt origins were identified by a graphical technique that distinguishes between multiple sources (Panno et al. 2006). This approach discriminates sea salt from, for instance, vacuum salt used as road salt. An average of $40 \%$ of Danish de-icing salt is vacuum salt. Both $\mathrm{Cl}$ and $\mathrm{Br}$ form stable anions in water, which are usually not affected by sediment-water reactions. In addition, $\mathrm{NaBr}$ is less soluble than $\mathrm{NaCl}$. As a consequence of the production process, vacuum salt has a $\mathrm{Cl} / \mathrm{Br}$ mass ratio $>1000$. Sedimentary rock salt, and hence road salt coming from this source, has $\mathrm{Cl} / \mathrm{Br}$ mass ratios similar to rain, as well as residual and infiltrating waters with a $\mathrm{Cl} / \mathrm{Br}$ mass ratio $<400$ (Davis et al. 1998). Based on a literature review and own data analyses, we find that $\mathrm{Cl} / \mathrm{Br}$ ratios are appropriate to detect the origin of dissolved $\mathrm{Cl}$ sources in Danish groundwater (Kristiansen et al. 2009).
The chemical indicator analysis shows that the potential impact of road salt on groundwater can be traced using a combination of $\mathrm{Cl} / \mathrm{Br}$ mass and $\mathrm{Na} / \mathrm{Cl}$ molecular ratios in groundwater where the $\mathrm{Na} / \mathrm{Cl}$ ratio is affected by the exchange of sodium between the solid and liquid phases and the $\mathrm{Cl} / \mathrm{Br}$ ratio is affected by the above-mentioned dissolution processes.

\section{Groundwater chloride sources}

Firstly, a prevalence of $\mathrm{Br}$-poor groundwater $(\mathrm{Cl} / \mathrm{Br}$ mass ratios $>1000)$ was found in upper groundwater $(<80 \mathrm{~m}$ below surface), which indicates that anthropogenic $\mathrm{Cl}$ sources (e.g. vacuum salt from roads, atmospheric deposition, or animal manure from farming) have a general impact on groundwater quality. Secondly, groundwater with reversed ionic exchange $(\mathrm{Na} / \mathrm{Cl}$ molecular ratio $<0.75)$ was also preferentially found in upper groundwater, which indicates infiltration of $\mathrm{NaCl}$ containing water into more fresh sediment. Thirdly, most

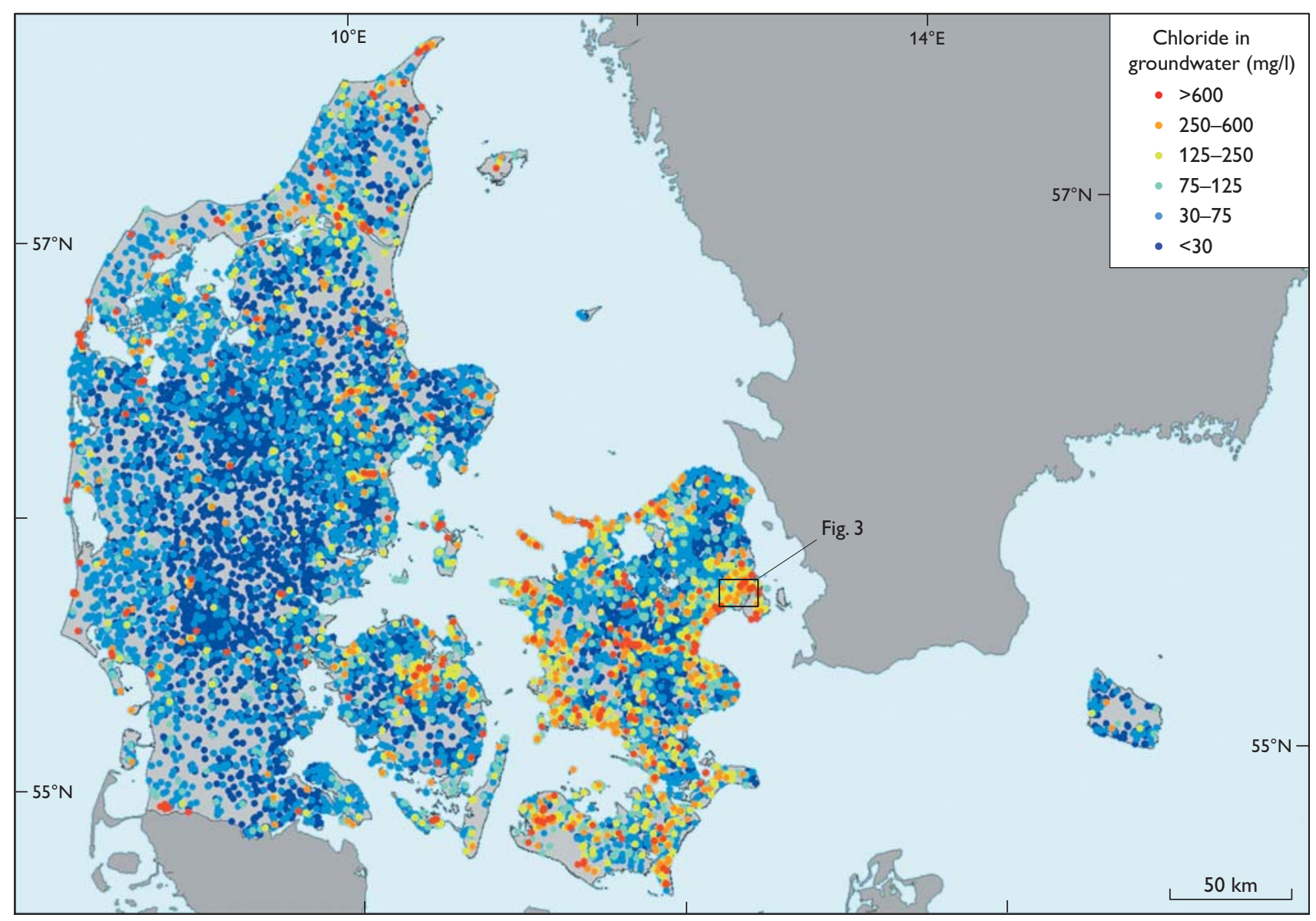

Fig. 2. Geographical distribution of the latest analysed chloride concentration in $c .24000$ Danish groundwater sampling points. The highest measured chloride concentration in wells with more than one measuring point is shown. Data were downloaded from the national database Jupiter in October 2008. 
Fig. 3. Modelling results of chloride concentrations in the primary aquifer due to leaching of road salt estimated for a steady-state situation in 2060 in the greater Copenhagen area. The loss of historically used road salt is put to $15 \%$ and all factors are kept constant from 2008 to 2060. The background concentration of chloride is not included. For location see Fig. 2.

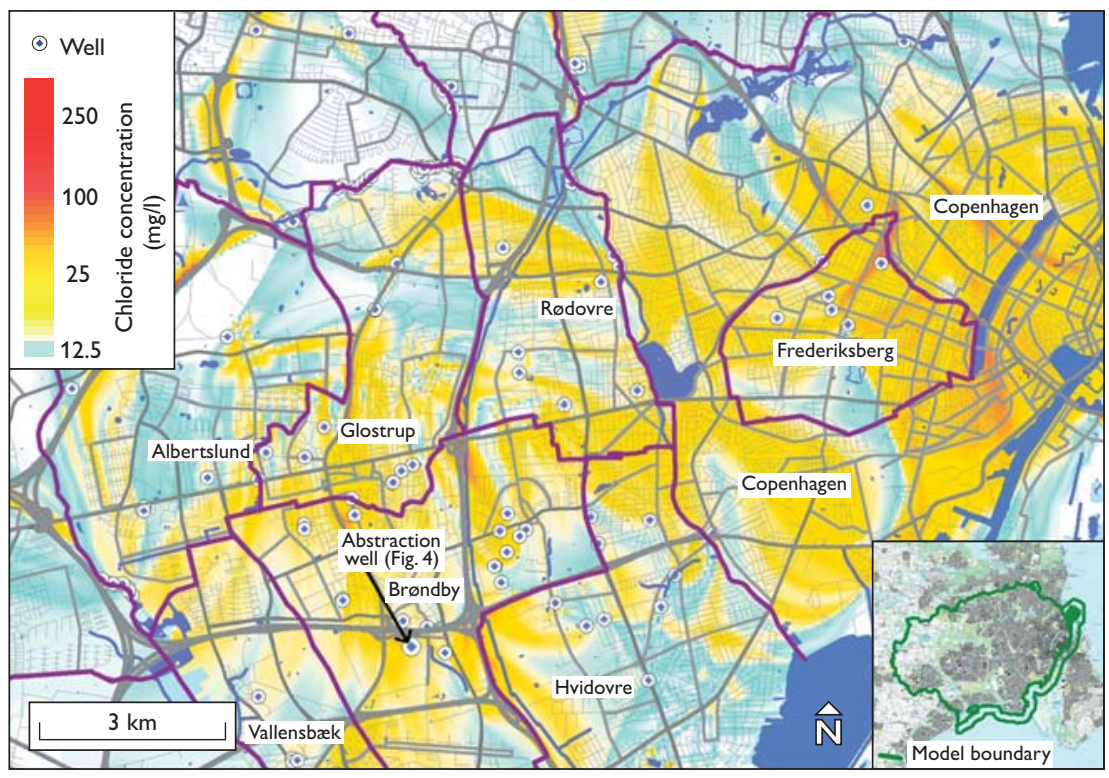

of the groundwater with high $\mathrm{Cl}$ concentrations was found in the upper groundwater with a gradual decrease from the surface to about $80 \mathrm{~m}$ below surface. These three different analyses support that the upper groundwater is affected by $\mathrm{Cl}$ sources at the soil surface. However, the analyses could not identify which specific type of $\mathrm{Cl}$ source at the surface influences groundwater quality.

In addition, the analyses showed that the deeper groundwater ( $>90 \mathrm{~m}$ below surface) often had $\mathrm{Cl} / \mathrm{Br}$ mass ratios $<550$; moreover, a gradual increase in $\mathrm{Cl}$ concentrations with depth indicated that the primary $\mathrm{Cl}$ source in deeper Danish aquifers should be found in the underlying groundwater with much higher $\mathrm{Cl}$ concentrations.

\section{Chloride distribution in Danish groundwater}

The $\mathrm{Cl}$ concentration classes used in Fig. 2 are based on statistical analysis of the distribution of all the $\mathrm{Cl}$ analyses from Danish groundwater where four geochemical populations are found: $<10,10-30,30-600$ and $>600 \mathrm{mg} \mathrm{Cl} / \mathrm{l}$. Background concentrations of $\mathrm{Cl}$ in Danish groundwater is below $30 \mathrm{mg} / \mathrm{l}$. Groundwater with $\mathrm{Cl}$ concentrations above the drinking water standard of $250 \mathrm{mg} / \mathrm{l}$ is commonly found close to the coastline, especially in the eastern parts of Denmark (Fig. 2). However, elevated concentrations of $\mathrm{Cl}$ are also found in inland aquifers.

Trend analyses of the $\mathrm{Cl}$ concentration in the groundwater in the greater Copenhagen area show that $38 \%$ of the wells have experienced significantly increasing concentrations whereas only $9 \%$ have seen significantly decreasing concentrations (95\% confidence interval) since the 1960s. Median
$\mathrm{Cl}$ concentrations in groundwater rose from $40-80 \mathrm{mg} / \mathrm{l}$ in $1965-1978$ to $80-160 \mathrm{mg} / \mathrm{l}$ in $1994-2007$. A predominance of inversed ionic exchanged groundwater indicates that infiltration of salt water into a fresher aquifer comes from anthropogenic influenced sources such as road salt or intrusion by sea water due to drinking water abstraction.

\section{Numerical modelling of road salt impact}

A numerical assessment tool was developed for a large part of the greater Copenhagen area $\left(274 \mathrm{~km}^{2}\right)$ in order to evaluate the impact of road salt on groundwater quality. We modelled losses of road salt to the environment at catchment scale from 1967 to 2060 (Fig. 3). The tool combines a surface load model with a well-calibrated 3D numerical groundwater model in MIKE SHE that simulates water flow and solute transport in the subsurface (Kristiansen et al. 2009). The surface load model consists of (1) the historic use of road salt since 2001 distributed on the road network where the type of road has been taken into consideration, (2) estimation of the loss of road salt to the groundwater, and (3) simple 1D modelling of the $\mathrm{Cl}$ transport through the unsaturated zone.

The loss of road salt to the surroundings is difficult to estimate, but Tvedt et al. (2001) estimated that 15-30\% of the road salt is lost under Danish conditions. However, not all the lost road salt infiltrates the groundwater as some percolating water is removed by drainage or sewage. In the modelling, we decided to use a loss of $15 \%$ of the road salt to groundwater, which can be considered as a best estimate based on available knowledge.

Simulations indicate that with a loss of $15 \%$ of the applied road salt, the chloride concentrations below urban areas gen- 


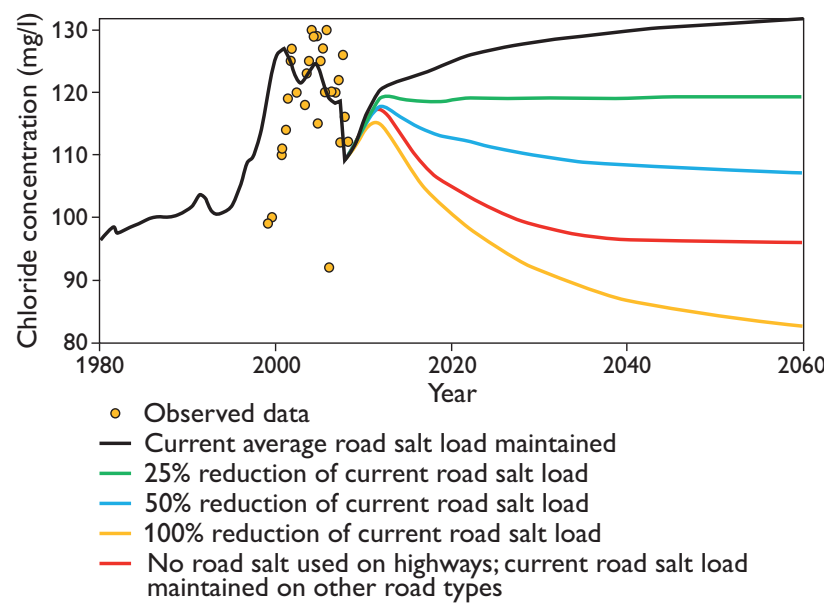

Fig. 4. Modelled and measured chloride concentrations in groundwater in an abstraction well in the greater Copenhagen area. For location see Fig. 3. Breakthrough curves are shown for different scenarios whereby road salt losses to groundwater are reduced.

erally will show a $25-40 \mathrm{mg} / \mathrm{l}$ increase, whereas increases can reach $125 \mathrm{mg} / \mathrm{l}$ at some major road junctions. Simulated breakthrough curves for a shallow well are shown in Fig. 4 for different scenarios compared to measured values. A background $\mathrm{Cl}$ concentration of $80 \mathrm{mg} / \mathrm{l}$ is added for the simulated results which contains $\mathrm{Cl}$ from natural sources as atmospheric deposition and marine residual water. The upper curve, where the current load of road salt is maintained, shows that it takes decades before a steady state situation is reached. The rest of the curves show the development of the groundwater $\mathrm{Cl}$ concentrations at steady state for different reduction scenarios in relation to current road salt usage.

\section{Conclusions}

The results show that the upper groundwater $\mathrm{Cl}$ concentrations ( $<80 \mathrm{~m}$ below surface) are affected by $\mathrm{Cl}$ sources such as road salt, atmospheric deposition and animal manure. Precise identification of the $\mathrm{Cl}$ sources at the surface requires more analyses of chemical indicator species in the groundwater. Numerical groundwater modelling in the greater Copenhagen area shows that road salt can result in a significant increase of the $\mathrm{Cl}$ concentration in groundwater, particularly near major road junctions. The aquifer used for water supply may be degraded because of the accumulated impact from several $\mathrm{Cl}$ sources such as road salt, residual salt groundwater and recent seawater intrusion. The applied model assumes that the loss to groundwater of road salt is $15 \%$. But if the loss was $30 \%$, then the resultant $\mathrm{Cl}$ concentration should be doubled. More precise quantification of the loss of road salt and knowledge on $\mathrm{Cl}$ sources other than salt applied to public roads are therefore required in order to reduce the uncertainty of the current estimate of the effect of road salt on groundwater quality, for example by establishing study sites in urban areas.

\section{Acknowledgement}

The project was supported by the former Environmental Centres under the Danish Ministry of the Environment.

\section{References}

Bester, M.L., Friend, E.O., Molson, J.W., Rudolph, D.L. 2006: Numerical investigation of road salt impact on an urban well-field. Ground Water 44, 165-175.

Bonnesen, E., Larsen, F., Sonnenborg, T., Klitten, K. \& Stemmerik, L. 2009: Deep saltwater in chalk of north-west Europe: origin, interface characteristics and development over geological time. Hydrogeology Journal 17, 1643-1663.

Davis, S., Cecil, D.W., Zreda, M. \& Sharma, P. 1998: Uses of chloride/ bromide ratios in studies of potable water. Ground Water 36, 338-350.

European Commission 2010: Report from the commission in accordance with article 3.7 of the groundwater directive 2006/118/EC on the establishment of groundwater threshold values, 10 pp. Brussels: European Commission.

European Environmental Agency 2009: Water resources across Europe confronting water scarcity and drought, 60 pp. Copenhagen: European Environmental Agency.

Jackson, R.B. \& Jabbogy, E.G. 2005: From icy roads to salty streams. Proceedings of the National Academy of Sciences of the United States of America 102, 14487-14488.

Kristiansen, S.M., Christensen, F.D. \& Hansen, B. 2009: Vurdering af danske grundvandsmagasiners sårbarhed overfor vejsalt, 107 pp. København: De Nationale Geologiske Undersøgelser for Danmark og Grønland.

Lundmark, A. \& Olofsson, B. 2007: Chloride deposition and distribution in soils along a deiced highway - assessment using different methods of measurement. Water, Air \& Soil Pollution 182, 173-185.

Ødum, H. \& Christensen, W. 1936: Danske Grundvandstyper og deres geologiske Optræden. Danmarks Geologiske Undersøgelse III. Række 26, 183 pp.

Panno, S.V., Hackley, K.C., Hwang, H.H., Greenberg, S.E., Krapac, I.G., Landsberger, S. \& O'Kelly, D.J. 2006: Characterization and identification of $\mathrm{Na}-\mathrm{Cl}$ sources in ground water. Ground Water 44, 176-187.

Tvedt, T., Randrup, T.B., Pedersen, L.B. \& Gludsted, S. 2001: Planter \& vejsalt, 19 pp. København: Trafikministeriet, Vejdirektoratet and Miljø- og Energiministeriet, Skov \& Landskab.

\footnotetext{
Authors' addresses

S.M.K., University of Aarhus, Department of Earth Sciences, Høegh-Guldbergs Gade 2, DK-8000 Aarhus C. E-mail: smk@geo.au.dk

F.D.C., Ramboll, Hannemanns Allé 53, DK-2300 Copenhagen S, Denmark.

B.H., Geological Survey of Denmark and Greeland, Lyseng Allé 1, DK-8270 Højbjerg, Denmark.
} 